Article

\title{
Influence of Tree Species, Harvesting Method and Storage on Energy Demand and Wood Chip Quality When Chipping Poplar, Willow and Black Locust
}

\author{
Ralf Pecenka ${ }^{1, *(\mathbb{D})}$, Hannes Lenz ${ }^{1}$, Simeon Olatayo Jekayinfa ${ }^{2}$ and Thomas Hoffmann ${ }^{1}$ \\ 1 Leibniz Institute for Agricultural Engineering and Bioeconomy e.V. (ATB), 14469 Potsdam, Germany; \\ hlenz@atb-potsdam.de (H.L.); thoffmann@atb-potsdam.de (T.H.) \\ 2 Ladoke Akintola University of Technology (LAUTECH), Ogbomosho PMB 4000, Nigeria; \\ sojekayinfa@lautech.edu.ng \\ * Correspondence: rpecenka@atb-potsdam.de; Tel.: +49-331-5699-312
}

Received: 19 February 2020; Accepted: 2 April 2020; Published: 6 April 2020

\begin{abstract}
The cultivation of fast-growing wood (e.g., poplar, willow or black locust) in short rotation coppices and agroforestry systems presents an opportunity for producing biomass sustainably in the agricultural sector. Cost-efficient agricultural wood production requires the availability of high-performance machinery and methods with which high-quality wood chips can be produced at low cost. It is known from harvesting short rotation coppices in practice that both the wood chip quality and the performance of the harvesting machinery depend on a variety of factors (e.g., harvesting method, weather conditions, tree species). That is why this study examines in detail the influence of the tree species (different varieties of poplar, willow, black locust) and the wood condition (fresh, stored or dried, frozen) on the specific energy demand for comminution in a stationary drum chipper and on the particle size distribution of the wood chips produced. For all the tree species examined, the chipping of dried as well as frozen stems was connected with a significant increase in the specific energy demand for comminution. An increase of $31 \%$ has been measured if poplar stems are chipped in frozen conditions (max. $6.31 \mathrm{kWh} \mathrm{t}^{-1}$ ). Drying led to an increase of $59 \%$ for dried willow stems (max. $6.67 \mathrm{kWh} \mathrm{t}^{-1}$ ). Drying and frost had also an influence on the size and quality of the wood chips, but no globally significant connection could be established for the examined tree varieties.
\end{abstract}

Keywords: agroforestry; short rotation coppice; poplar; willow; black locust; wood chips; comminution; energy demand; drying

\section{Introduction}

Trees planted on agricultural land present an opportunity for producing biomass sustainably and at the same time improving farm income. Fast-growing tree species such as poplar, willow and black locust cultivated in short rotation coppices (SRC) or agroforestry systems (AFS) offer not only considerable potential for producing plant biomass, but can also at the same time withdraw carbon from the atmosphere and store it in their biomass [1-6]. To be successful in competition with wood products from the forestry sector, various obstacles need to be overcome when expanding the cultivation of fast-growing agricultural timber crops. Such expansion is desirable for ecological reasons. The agricultural timber produced on farm land has so far preferably been used as a source of renewable energy for producing heat and electricity in regional cogeneration and power stations. For this, the harvested trees have to be converted to wood chips and frequently stored for relatively long periods [7-10]. Short rotation coppices are harvested in winter with moisture contents of 
$50-60 \mathrm{wt} \%$. Demand for the material continues throughout the year, however, and thus makes storage absolutely necessary. Dry matter losses of up to $30 \%$ can result from the hitherto customary method of storing and drying wood chips in naturally ventilated large outdoor piles for periods of more than 6 months $[6,8,11-13]$.

In addition to the necessary expertise concerning site-appropriate process design, in order to make agricultural wood production profitable it is also necessary to have efficient machinery available with which high-quality wood chips can be produced at low cost and easily handled during storage and transport [14-17]. It was established that depending on the biomass yields, the cultivation methods applied and the selection of the harvesting machinery, harvesting alone accounts for $35-60 \%$ of the total costs of biomass production in short rotation coppices [7,18-20]. In the past thirty years there have been many machinery-based attempts to make mechanical harvesting of short rotation coppices more efficient, but only few of these have achieved market maturity. Looking at the coupling of the individual process steps necessary for SRC harvesting, it is possible to differentiate basically between single-step and two-step methods (Figure 1) [21-23]. While in single-step harvesting (Figure 1, Systems $\mathrm{A}$ and $\mathrm{B})$ the trees are cut directly from the stump and chipped, in two-step harvesting comminution generally only takes place after relatively long storage and natural drying of the wood in the log deck (Figure 1, Systems C-E) [24-26].

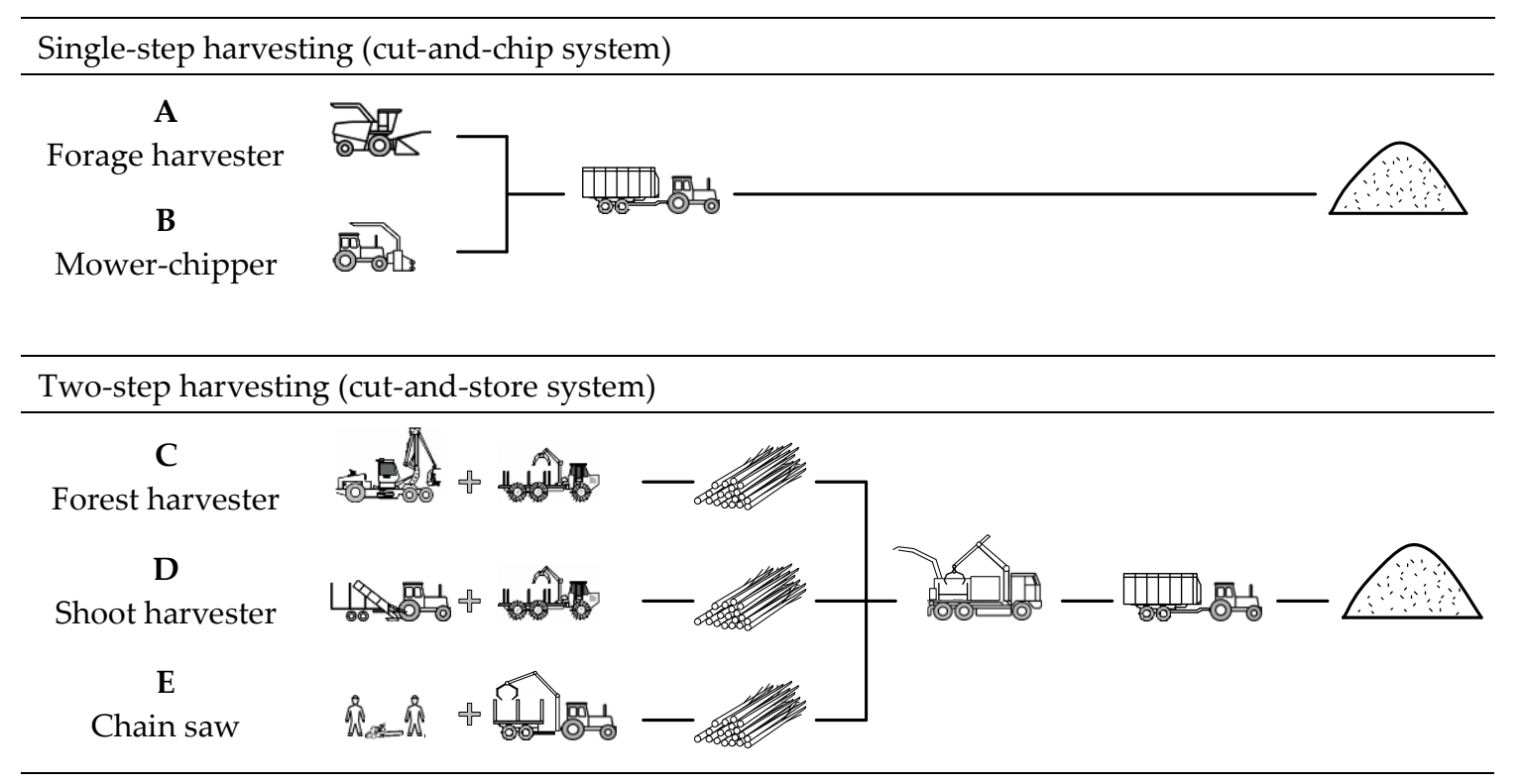

Figure 1. Single-step (A-B) and two-step (C-E) harvesting lines of agricultural wood and processing to wood chips.

In all methods, comminution of the trees to wood chips is the central process step, involving a high energy demand. Depending on the selection of the comminution machinery and the properties of the trees at the time of chipping-influenced for instance by variety, trunk diameter, age of the root stocks and shoots, water content, modification of the wood strength due to storage processes or frost-the quality of the wood chips is largely determined in this process. For cost-efficient production and marketing of high-grade wood chips, not only must the requirements of the valid standards be met, for instance as regards the fines fraction and the water and ash contents [27-29], but also the losses and the energy input along the entire process chain of wood chip production should be as low as possible [10,30-33]. The drying processes and losses during storage of the wood are crucially influenced by the nature of the wood conditioning and/or comminution during harvesting $[8,34,35]$.

To date, given the frequent lack of availability of suitable harvesting machinery in many cultivation regions, the selection of harvesting time and harvesting technology has frequently not been based on process engineering requirements. Instead, the harvest is mainly carried out by service providers who 
harvest the land in accordance with a fixed time schedule as soon as the soil is fit for driving on in the winter. As a general recommendation, wherever possible, it is best to harvest when the soil is frozen in order to avoid excessive loads on the soil together with the formation of deep furrows in the field by the machines $[9,10,36]$. However, as a consequence of adopting this practice, the trees can be frozen at this point in time. In our own trials, the chipping unit of the harvesting machinery frequently sustained damage particularly when harvesting during prolonged periods of severe frost. To what extent this is attributable to possibly different behavior of frozen trees from SRC during chipping has not been investigated sufficiently. However, it is known that sugar dissolved in the wood leads to a reduction in the freezing point of the water in the wood [37]. At temperatures below -5 to $-10{ }^{\circ} \mathrm{C}$, however, the water freezes in the wood too. Furthermore, it is known from the use of modified forage harvesters for harvesting SRCs and from the forestry sector that both the design of the chipping units and the condition of the blades and counter blades (degree of wear) exert substantial influence not only on the energy demand during chipping, but also on the quality of the wood chips [35,38-44].

The goal of this study was therefore to conduct a detailed analysis of the connection between tree species, the condition of the trees at the time of chipping (fresh, stored, frozen), the energy demand for comminution, and the quality of the wood chips produced.

\section{Materials and Methods}

\subsection{Test Stand for Determining the Specific Energy Demand}

The test stand shown in Figure 2 was used to determine the specific energy demand during comminution of wood logs and shoots from short rotation coppices. The core component of the test stand is a drum chipper (HE100 500 STA, JENZ, Petershagen, Germany), the basic structure of which corresponds to the mobile chippers generally used in forestry. On this test stand a defined mass flow of timber could be fed to the chipping drum via a conveyor belt. The electric drive (power rating 22 $\mathrm{kW}$ ) was controlled via a frequency inverter (SJ 300, Hitachi, Tokyo, Japan). With this it was possible to record the power consumption of the chipper during the comminution process and to store this on a connected measuring computer for detailed analysis (Hitachi ProDrive v1.9.1.1, sampling rate: 11 measurements per second, Hitachi, Tokyo, Japan). The knives of the chipper were sharpened before the trials in order to rule out any influencing of the results by wear of the blades. The chipper was equipped with a screen with rectangular holes ( $5 \mathrm{~cm}$ screen width).

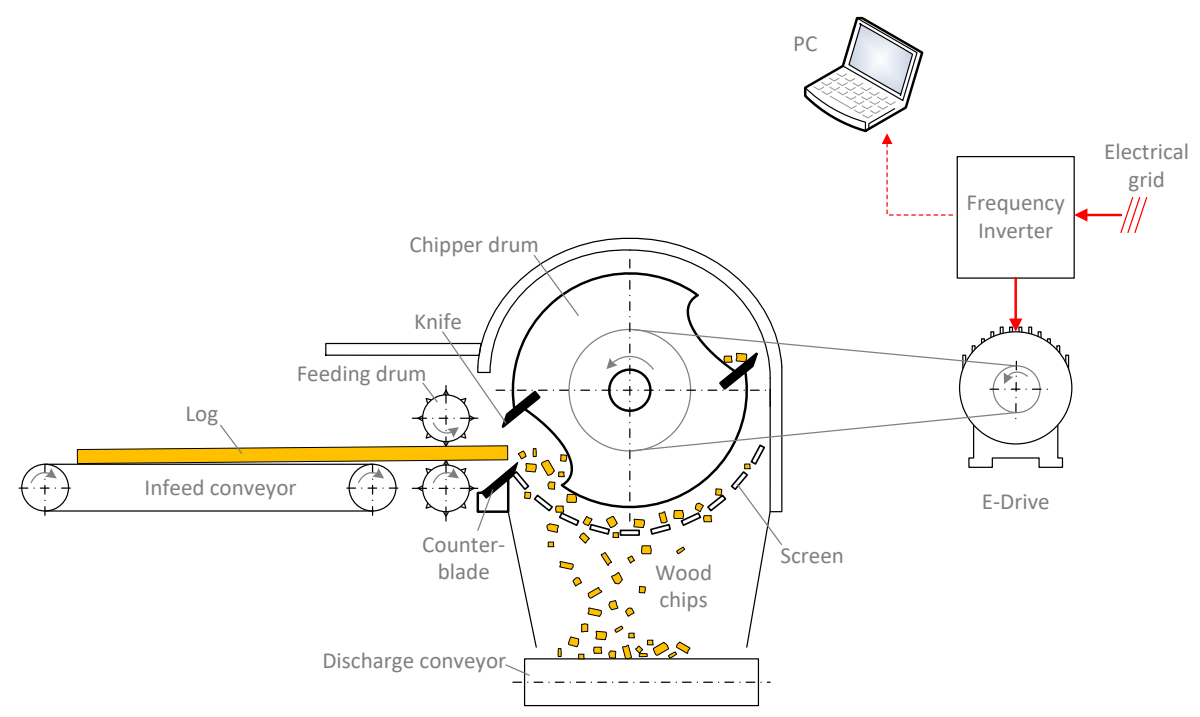

Figure 2. Test stand for determining the specific chipping energy demand. 


\subsection{Raw Material Properties, Sample Preparation and Performance of Trials}

Trunks of different poplar, willow and black locust varieties were examined in the trials for their comminution behaviour. In some measurements we additionally varied the condition of the raw timber material (fresh, stored, frozen) as an essential parameter for the energy demand and wood chip quality. The parameters investigated here for different raw material conditions of the stems during chipping were:

(a) Freshly harvested wood: the trees were harvested in February/March and chipped immediately.

(b) Dried wood: the trees were harvested in February/March, then stored out in the open for several months and at the same time dried naturally. Chipping was only carried out following this roughly nine-month storage period.

(c) Frozen wood: the trees were harvested in February/March and cut into logs of $2 \mathrm{~m}$ length. These logs were put into a freezing chamber and stored at minus $18{ }^{\circ} \mathrm{C}$ for seven days. After this freezing treatment the logs were chipped immediately in frozen condition.

As it was assumed that the size of the trees also influences the chipping process, the tree diameters were also varied in some trials. Table 1 provides an overview of the various wood ranges and timber conditions used for the comminution trials. The majority of all material samples have been collected at the research plantations of the Leibniz Institute for Agricultural Engineering and Bioeconomy (ATB) in Potsdam. In addition, three willow samples have been provided by Rothamsted Research, Harpenden/England (Willow SV E, Table 1).

Table 1. Characteristics of poplar, willow and black locust used for comminution experiments.

\begin{tabular}{|c|c|c|c|c|}
\hline Variety & $\begin{array}{c}\text { Stem Diameter } \\
{[\mathrm{cm}]}\end{array}$ & $\begin{array}{c}\text { Number of Shoots } \\
\text { per Trial }\end{array}$ & Condition & Label $^{1}$ \\
\hline \multirow{4}{*}{ Poplar Max ${ }^{2}$} & $3.5 \ldots 4$ & 4 & wet & P-M-w-4 \\
\hline & $3.5 \ldots 4$ & 4 & dried & P-M-d-4 \\
\hline & $3.5 \ldots 4$ & 4 & frozen & P-M-f-4 \\
\hline & $5 \ldots 6$ & 2 & wet & P-M-w-2 \\
\hline Poplar AF2 & $5 \ldots 6$ & 2 & wet & P-A-w-2 \\
\hline \multirow{4}{*}{ Poplar H275 } & $5 \ldots 6$ & 2 & wet & P-H-w-2 \\
\hline & 7.9 & 1 & frozen & P-H-f-1 \\
\hline & $3.5 \ldots 4$ & 4 & frozen & P-H-f-4 \\
\hline & $3.5 \ldots 4$ & 4 & wet & P-H-w-4 \\
\hline Black Locust $^{3}$ & $3.5 \ldots 4$ & 4 & wet & B-L-w-4 \\
\hline Willow Inger & $3.0 \ldots 4$ & 5 & wet & W-I-w-4 \\
\hline \multirow[b]{2}{*}{ Willow SV G ${ }^{4}$} & $2.5 \ldots 3$ & 9 & dried & W-S-d-9 \\
\hline & $2.5 \ldots 3$ & 9 & wet & W-S-W-9 \\
\hline \multirow{2}{*}{ Willow Tordis } & $3.5 \ldots 4$ & 4 & frozen & W-T-f-4 \\
\hline & $3.5 \ldots 4$ & 4 & wet & W-T-w-4 \\
\hline \multirow{3}{*}{ Willow SV E 5} & $2.9 \ldots 3$ & 7 & dried & W-S-d-7 \\
\hline & $2.5 \ldots 2.8$ & 7 & wet & W-S-W-7 \\
\hline & $1.8 \ldots 2$ & 15 & dried & W-S-d-15 \\
\hline
\end{tabular}

${ }^{1}$ Labelling: Variety-Clone-Condition-No of shoots per trial. Example for labelling: W-S-d-15 = Willow, clone Salix viminalis, dried shoots, 15 shoots per chipping trial. ${ }^{2}$ Poplar Max1 and Max4. ${ }^{3}$ Black Locust $1 \mathrm{jS} 1 / 0 .{ }^{4}$ Salix viminalis 12 from Leibniz Institute of Agricultural Engineering and Bio-economy (ATB), Germany. ${ }^{5}$ Salix viminalis from Rothamsted Research, England.

The mass of the wood samples fed in and the moisture content had to be determined to investigate the specific energy demand. The stems and shoots used for the measurements were therefore weighed separately before comminution for each round of the experiment (fresh mass, Satorius BP12000S balance, Goettingen, Germany, $\mathrm{d}=0.1 \mathrm{~g}$ ). The wood moisture content was determined with the help of 
three samples of the wood chips produced in the respective trial round (Oven-Dry-Method, EN ISO 18134-2 [45]). The particle size analysis and the classification into size categories were carried out on the basis of EN ISO 17827-1 and EN ISO17225-1 [27,46] using three further samples of the wood chips in each case. The median value $\left(\mathrm{d}_{50}\right)$ of the particle size distribution curves (shown as cumulative frequency of wood particles passing screens with different sizes according to EN ISO 17827-1 [46,47]) has been used to evaluate the influence of different treatments on the average size of the produced wood chips. The $d_{50}$ was determined as the intersection between the horizontal $50 \%$ line $\left(d_{50}\right)$ and the rectilinear connection of the measurement points closest to this $50 \%$ line. All the comminution experiments were repeated four times. Feeding of the chipper while ensuring comparable comminution conditions for samples with greatly differing stem diameters turned out to be a particular problem. In order to ensure the same conditions as far as possible, the samples were bundled for each round of the trials in such a way that the mean stem diameter of the wood samples selected only varied slightly (max. 10\%) and the total of the cross-section areas of the selected stems for a trial round was always 48 to $50 \mathrm{~cm}^{2}$ (Figure 3; Figure 4). This made it possible to guarantee a constant filling degree of the chipper and hence uniform framework conditions for all comminution experiments. Depending on the timber variety, the weight of a chipping sample was between 7.5 and $10 \mathrm{~kg}$ for the fresh samples, and between 4.9 and $5.6 \mathrm{~kg}$ for the dried samples. In addition, all the branches were removed from the logs prior to chipping and the logs were cut to a length of $2 \mathrm{~m}$.

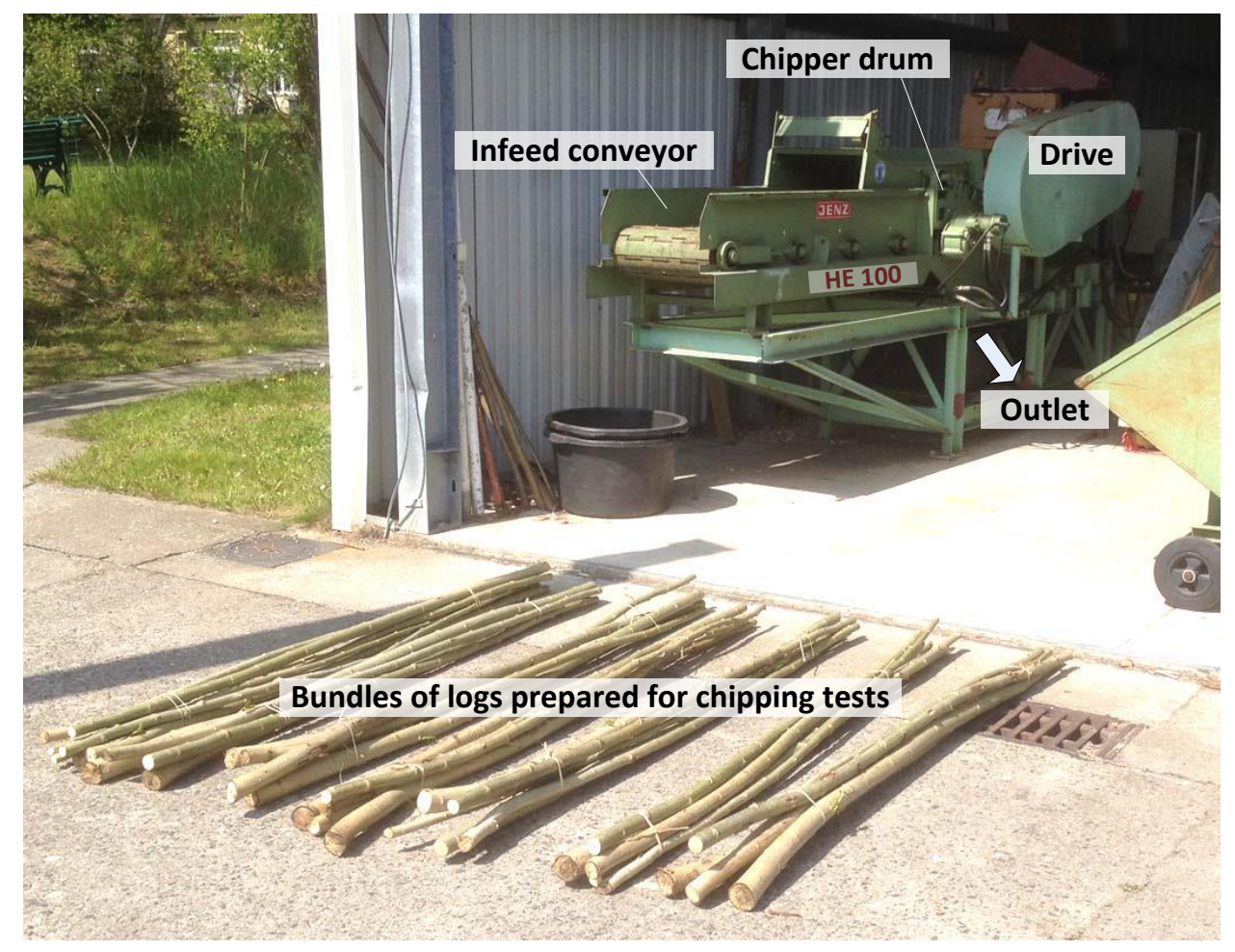

Figure 3. Bundling of the chipping samples and setup of the experimental stand (chipper HE 100500 , JENZ, Petershagen, Germany). 


\section{Sample}

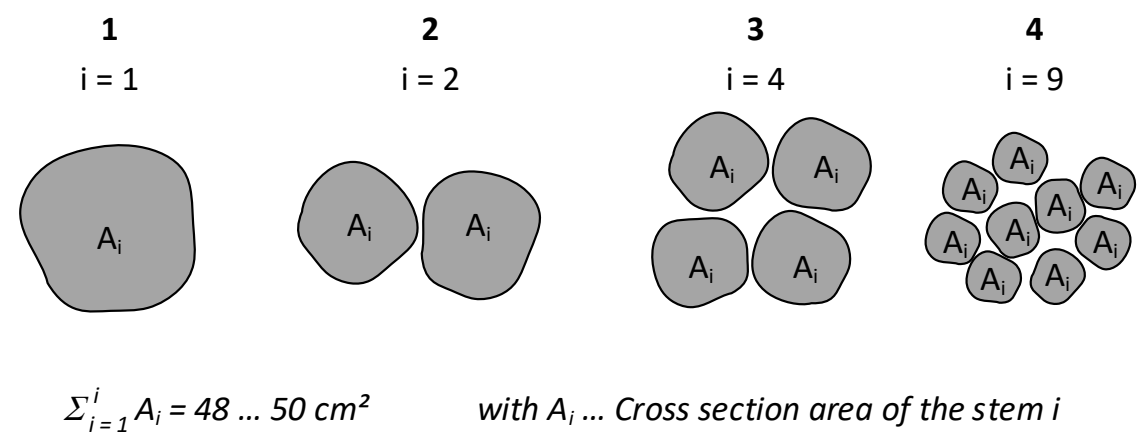

Figure 4. Method for arranging chipping samples with the same cross section area.

\subsection{Specific Energy Demand}

The specific energy demand $W_{\text {spec }}$ for the chipping process was determined on the basis of the average power recorded in the measuring curves during the chipping process as shown in Figure 5.

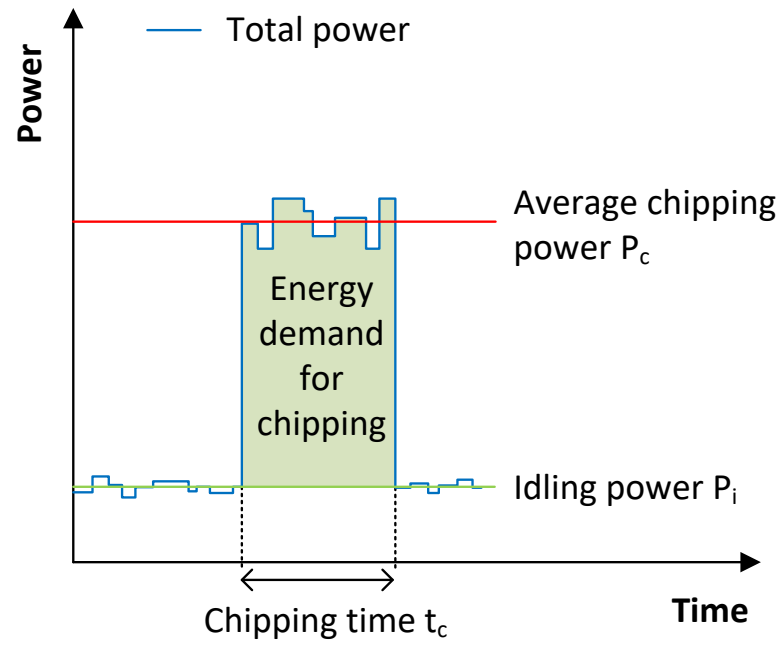

Figure 5. Determining the mean energy demand for comminution of wood in a drum chipper, taking idling power into account $\left(\mathrm{P}_{\mathrm{c}}\right.$ average chipping power; $\mathrm{P}_{\mathrm{i}}$ Idling power; $\mathrm{t}_{\mathrm{c}}$ chipping time).

Taking into account the dry wood matter comminuted during the measurement, it was than possible to calculate the specific energy demand for chipping a wood sample as follows (Equation (1)) [44]:

$$
W_{\text {spec }}=\frac{\left(P_{c}-P_{i}\right) \times t_{c}}{3600 \times m_{d}} \times 1000
$$

$\mathrm{W}_{\text {spec, }}$ specific energy demand for chipping on dry matter basis $\left[\mathrm{kWh} \mathrm{t}^{-1}\right] ; \mathrm{P}_{\mathrm{c}}$, average power consumption during chipping $[\mathrm{kW}] ; \mathrm{P}_{\mathrm{i}}$, average power consumption during idling $[\mathrm{kW}] ; \mathrm{t}_{\mathrm{c}}$, time required for chipping of one sample $[\mathrm{h}] ; \mathrm{m}_{\mathrm{d}}$, dry matter of the processed sample $[\mathrm{t}]$.

\subsection{Statistical Analysis}

The results were evaluated by the statistical software SAS v9.4 (SAS Institute Inc., Cary, NC, USA). For evaluation of the data the procedure GLIMMIX was used in order to carry out a two factorial ANOVA. The GLIMMIX procedure adapts statistical models to data with correlations or non-constant variability, homogeneous or non-homogeneous variances where the response is not necessarily normally distributed. Due to the interactions between the two factors only the twofold 
effect was considered. In the following figures, treatments labelled by different letters are different according to GLIMMIX procedure with $p \leq 0.05$.

\section{Results}

\subsection{Specific Energy Demand}

Table 2 provides an overview of the results of the specific energy demand measurements and the mean particle size produced when chipping different timber ranges. The results show that there are relatively large differences in the specific energy demand, not only depending on the variety, but also depending on the condition of the stems (freshly harvested, dried or frozen). Chipping of thin willow shoots (seven freshly harvested stems per trial) required the least energy, displaying a specific energy demand of $4.03 \mathrm{kWh} \mathrm{t}^{-1}$ (Trial No. W-S-w-7). A comparison of the comminution experiments that were conducted with four fresh and distinctly thicker stems in each case reveals that the chipping of poplar of the Max variety requires the least energy at $4.81 \mathrm{kWh} \mathrm{t}^{-1}$, followed by willow (Tordis $5.63 \mathrm{kWh} \mathrm{t}^{-1}$, Inger $\left.5.87 \mathrm{kWh} \mathrm{t}^{-1}\right)$, black locust $\left(6.28 \mathrm{kWh} \mathrm{t}^{-1}\right)$ and the poplar Hybrid $275\left(6.50 \mathrm{kWh} \mathrm{t}^{-1}\right)$, see also Figure 6.

Table 2. Specific energy demand and median particle size of the wood chips produced for different tree species.

\begin{tabular}{|c|c|c|c|c|c|}
\hline Variety & Trial No. ${ }^{1}$ & $\begin{array}{c}\text { Moisture } \\
\text { Content [\%] }\end{array}$ & $\begin{array}{c}\text { Particle Size } \\
\mathrm{d}_{50}{ }^{2} \\
{[\mathrm{~mm}]}\end{array}$ & $\begin{array}{l}\text { Content of } \\
\text { Fines }{ }^{3}[\%]\end{array}$ & $\begin{array}{c}\text { Specific Energy } \\
\text { Demand }^{4} \\
{\left[\mathrm{kWh} \mathrm{t}^{-1}\right]}\end{array}$ \\
\hline \multirow{4}{*}{ Poplar Max } & P-M-w-4 & 54.5 & 12.7 & $3.2(0.07)$ & $4.81(0.31)$ \\
\hline & P-M-d-4 & 34.8 & 10.9 & $5.1(0.11)$ & $5.44(0.26)$ \\
\hline & P-M-f-4 & 57.0 & 11.9 & $4.0(0.83)$ & $6.31(0.41)$ \\
\hline & P-M-w-2 & 59.4 & 12.0 & $3.6(0.09)$ & $6.37(0.03)$ \\
\hline Poplar AF2 & P-A-w-2 & 61.1 & 11.4 & $4.3(0.08)$ & $6.44(0.21)$ \\
\hline \multirow{4}{*}{ Poplar H275 } & P-H-w-2 & 51.6 & 14.8 & $4.0(0.12)$ & $7.87(0.10)$ \\
\hline & P-H-f-1 & 55.8 & 12.0 & $4.3(0.07)$ & $9.16(1.20)$ \\
\hline & P-H-f-4 & 51.5 & 12.2 & $4.9(0.14)$ & $7.93(0.25)$ \\
\hline & P-H-w-4 & 50.5 & 13.8 & $2.1(0.12)$ & $6.50(0.16)$ \\
\hline Black Locust & B-L-w-4 & 40.8 & 12.2 & $4.2(0.11)$ & $6.28(0.18)$ \\
\hline Willow Inger & W-I-w-4 & 46.8 & 11.1 & $5.7(0.15)$ & $5.87(0.28)$ \\
\hline \multirow{2}{*}{ Willow SV G } & W-S-d-9 & 24.6 & 10.4 & $8.6(0.05)$ & $6.67(0.52)$ \\
\hline & W-S-w-9 & 40.5 & 12.9 & $3.7(0.08)$ & $4.21(0.15)$ \\
\hline \multirow{2}{*}{ Willow Tordis } & W-T-f-4 & 48.4 & 12.1 & $3.8(0.04)$ & $6.46(0.51)$ \\
\hline & W-T-w-4 & 50.4 & 11.5 & $3.9(0.06)$ & $5.63(0.17)$ \\
\hline \multirow{3}{*}{ Willow SV E } & W-S-d-7 & 26.8 & 13.3 & $2.0(0.23)$ & $5.35(0.21)$ \\
\hline & W-S-w-7 & 45.6 & 12.6 & $3.5(0.14)$ & $4.03(0.14)$ \\
\hline & W-S-d-15 & 23.7 & 14.6 & $2.7(0.21)$ & $5.84(0.26)$ \\
\hline
\end{tabular}

${ }^{1}$ Labelling: Variety-Clone-Condition-No of shoots per trial. Example for labelling: W-S-d-15 = Willow, clone Salix viminalis, dried shoots, 15 shoots per chipping trial. ${ }^{2}$ Median value of the particle size distribution. ${ }^{3}$ Dry matter mass fraction smaller than $3.15 \mathrm{~mm}$ (EN ISO 17225-1), standard deviation in brackets. ${ }^{4}$ On dry matter basis, standard deviation in brackets.

For the poplar varieties Max and Hybrid 275, the influence of the stem diameter on the energy demand during chipping was examined in detail. It was shown that an increase in the stem diameter of both poplar varieties also led to a significant increase in the energy demand for comminution. In the same way, in all trials significantly more energy was required for chipping frozen stems-the energy demand increased by $15 \%$ to $31 \%$ depending on the variety (four stems per trial, Figure 7 ). An additional increase in the stem diameter led to a considerable but statistically non-significant rise in the energy demand for frozen trees. As a consequence, chipping of a single, frozen, very thick log with a 
cross section area equivalent to four stems displayed the highest specific energy demand $\left(9.16 \mathrm{kWht}^{-1}\right.$, trial P-H-f-1) measured in all the trials.

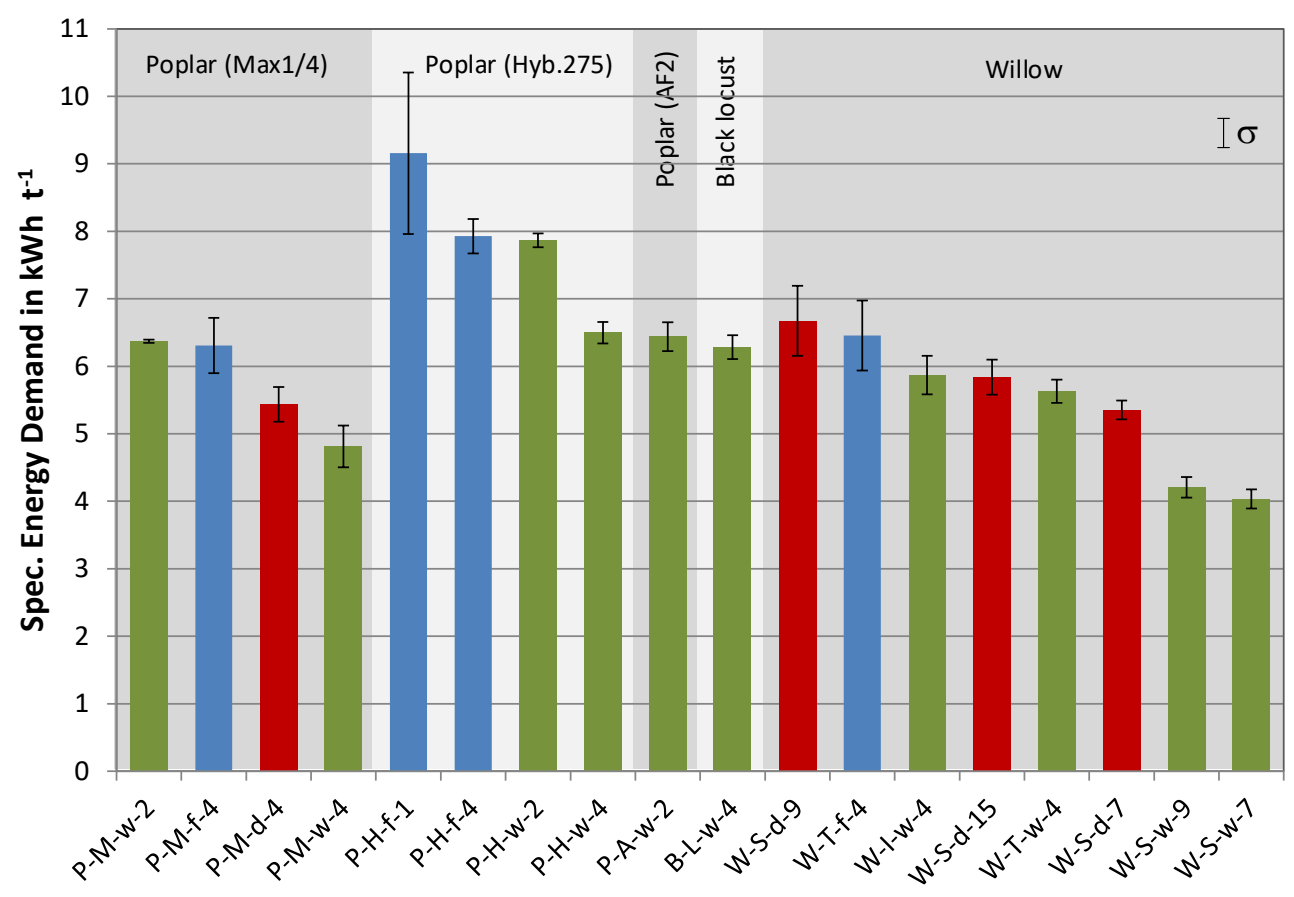

Figure 6. Overview of the specific energy demand for chipping poplars, willows and black locusts from short rotation coppices (SRCs) in fresh, dried and frozen conditions (colors: green = fresh, dried $=$ red, blue $=$ frozen); Labelling of trials on $\mathrm{x}$-axis: Variety-Clone-Condition-No of shoots per trial. Example for labelling: W-S-d-15 = Willow, clone Salix viminalis, dried shoots, 15 shoots per chipping trial, see Table 1.

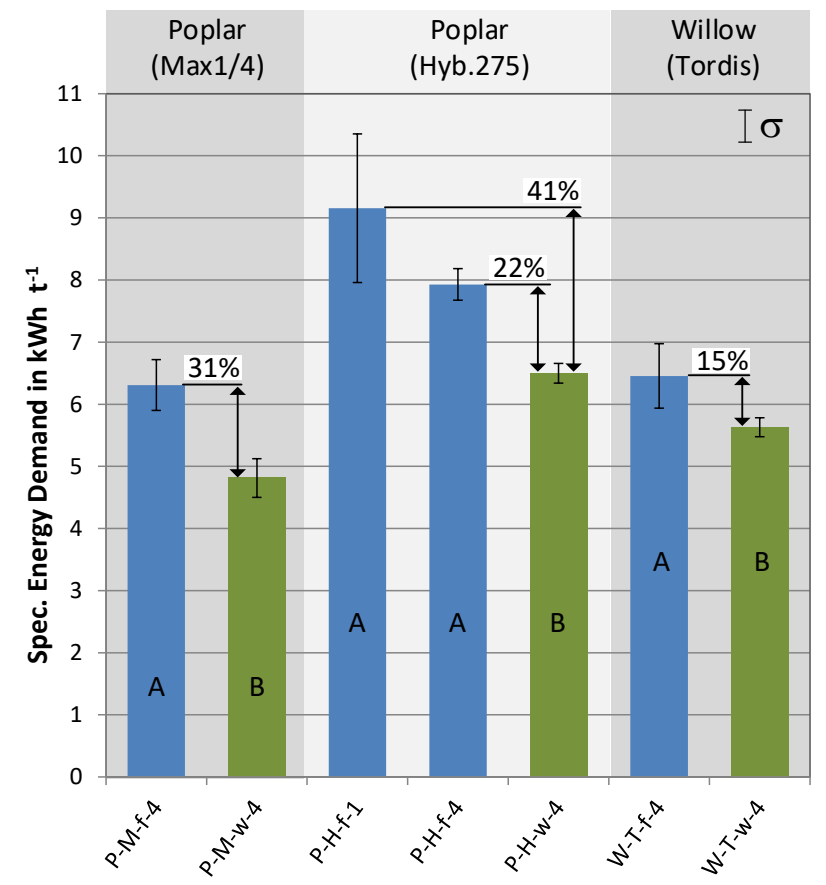

Figure 7. Comparison of the specific energy demand for chipping fresh and frozen poplars and willows from SRCs (colors: green $=$ fresh, blue $=$ frozen; different letters indicate significant differences between trials $(p \leq 0.05))$; Labelling of trials on $\mathrm{x}$-axis: see Table 1 . 
In addition, more energy is also required for chipping dried trees from SRCs (Figure 8). Accordingly, the specific energy demand for chipping dried poplars (variety Max) increased significantly by approx. $13 \%$ and for dried willows (variety Salix viminalis from England) by as much as 33\%. The chipping of bundles of very thin, dried willow shoots (diameter of the individual shoots 1.8 to $2 \mathrm{~cm}$, trial W-S-d-15) required approx. $9 \%$ more energy by comparison with thicker dried shoots of the same variety (diameter 2.9 to $3 \mathrm{~cm}$, trial W-S-d-7).

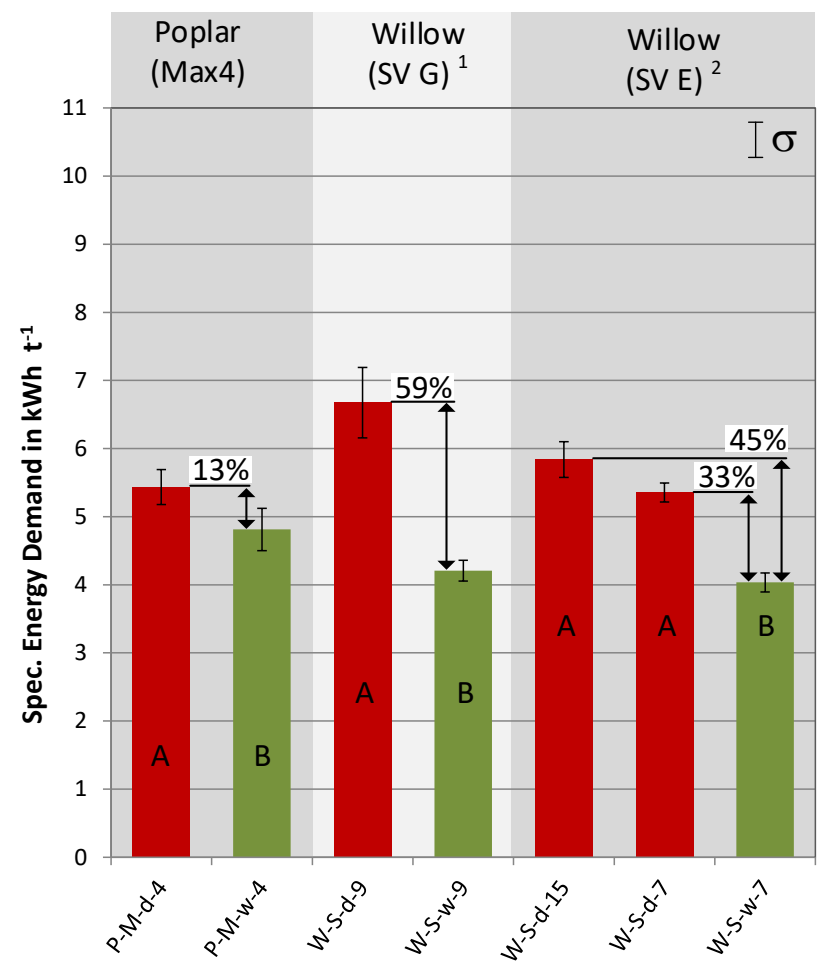

Figure 8. Comparison of the specific energy demand for chipping fresh and dried poplars and willows from SRCs (colors: green $=$ fresh, red $=$ dried; different letters indicate significant differences between trials $(p \leq 0.05)) .{ }^{1}$ Salix viminalis from ATB, Germany. ${ }^{2}$ Salix viminalis from Rothamsted Research, England; Labelling of trials on $\mathrm{x}$-axis: see Table 1.

\subsection{Particle Analysis}

Figures 9-11 show the results of the particle size analysis for the different wood varieties. The median values of the particle size $\left(\mathrm{d}_{50}\right)$ are additionally listed in Table 2 for a better comparison of the trial results.

Figure 9 shows the connection between the particle size distribution and variety for the trials with freshly harvested samples (four stems per chipping trial). It is evident from this that the willow varieties examined supply the finest wood chips, followed by black locust and poplar. If the results obtained with fresh trees and four stems in each case are compared, the poplar variety Hybrid 275 with a median value $\mathrm{d}_{50}$ of approx. $13.8 \mathrm{~mm}$ produces the coarsest wood chips, and willow of the Inger variety with a median value of 11.1 produces the finest wood chips. When a smaller number of thicker trees were chipped, the trials with the poplar variety Hybrid 275 showed a rise of approx. $7 \%$ in the median value of the particle size distribution $\left(\mathrm{d}_{50}=14.8\right.$ for two trees, Table 2, trial P-H-w-2).

Figure 10 shows the effect of frost and drying on the particle size distribution of poplar wood chips. The chipping of both frozen and dried stems led to a reduction in the particle sizes (see the median values in Table 2). For poplar stems (variety Max) the median value of the particle size distribution was reduced from $12.7 \mathrm{~mm}$ to $11.9 \mathrm{~mm}$ for frozen stems and to $10.9 \mathrm{~mm}$ for dried stems (reduction by $5 \%$ and $13 \%$ respectively). If one considers the screen fraction relevant for classification of the wood chips into different quality and fines fraction classes up to $3.15 \mathrm{~mm}$ screen aperture diameter, the mass 
fraction in these classes grew as a result of drying and frost. Wood chips from freshly chipped poplar (trial P-M-w-4) contained a fines fraction of only 3.2\%, while wood chips from poplars of the same variety and diameter chipped after drying contained a fines fraction of $5.1 \%$ (trial P-M-d-4) and wood chips from frozen poplars contained a fines fraction of 4.0\% (trial P-M-f-4). The comparison between different wood species chipped under comparable conditions (wet, 4 shoots) shows, that the content of fines in chips from willow and black locust is higher (3.9-5.7\%) than in chips from poplar (2.1-3.2\%).

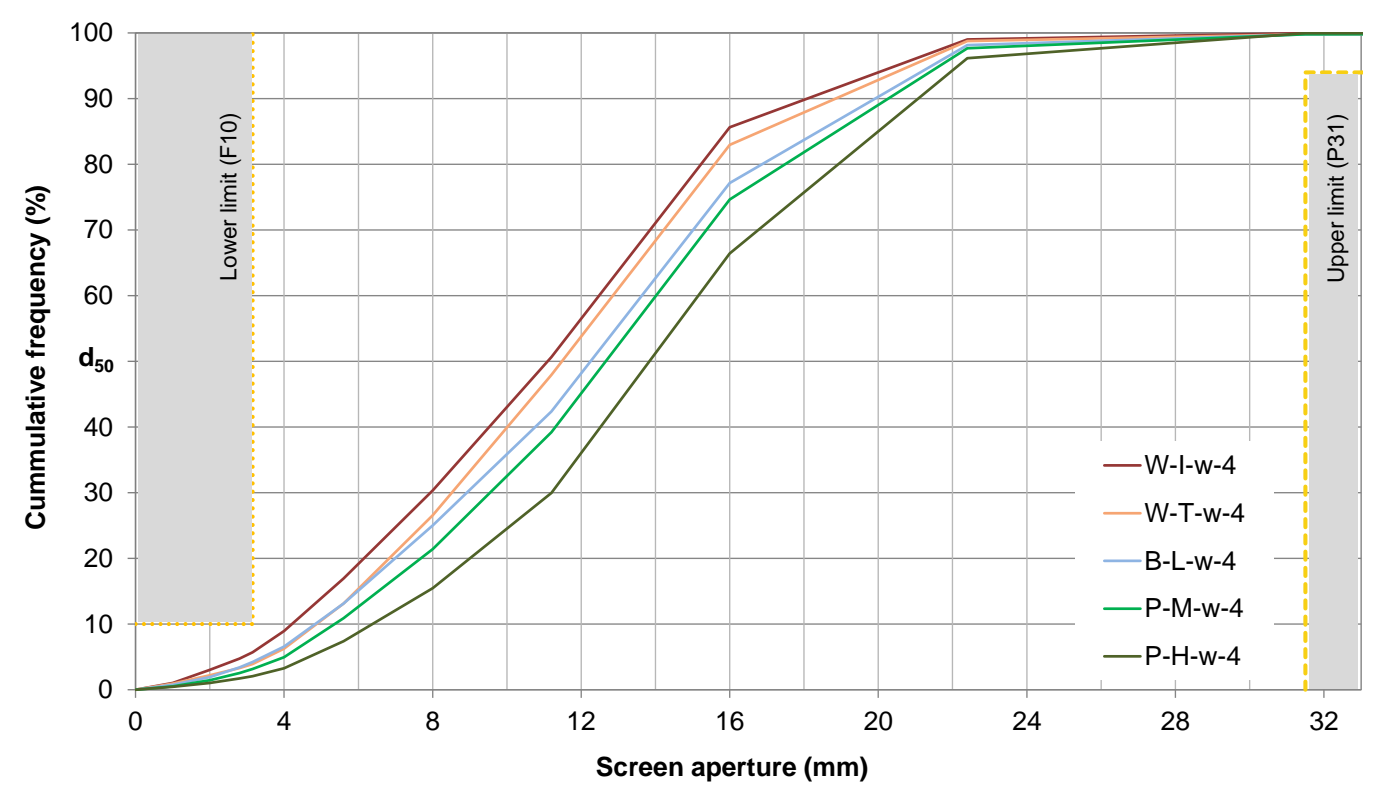

Figure 9. Particle size distribution for fine wood chips from poplar, willow and black locust and standard ranges according to EN ISO 17225-1; Labelling of trials: see Table 1.

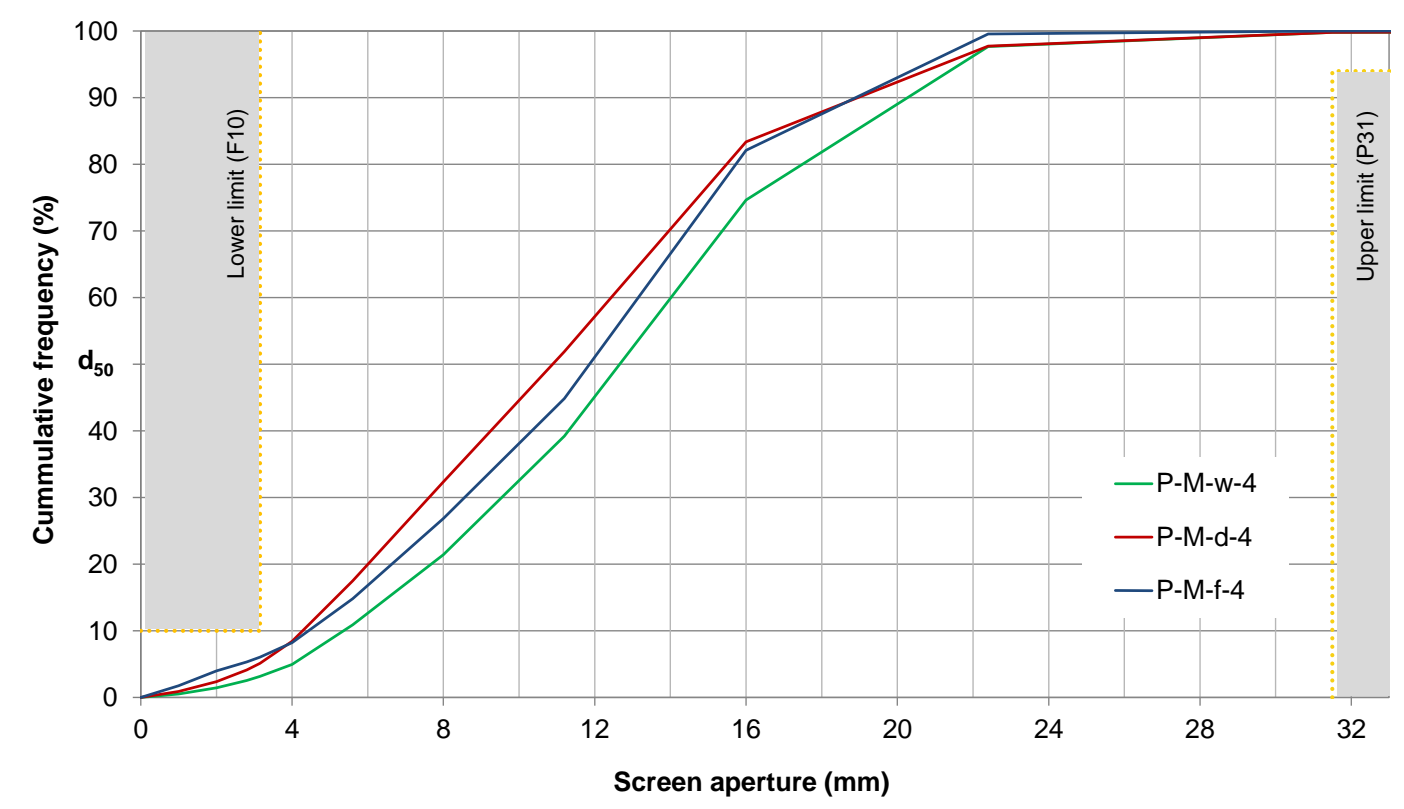

Figure 10. Particle size distribution for fine wood chips from fresh, dried and frozen poplars (variety Max) and standard ranges according to EN ISO 17225-1; Labelling of trials: see Table 1. 


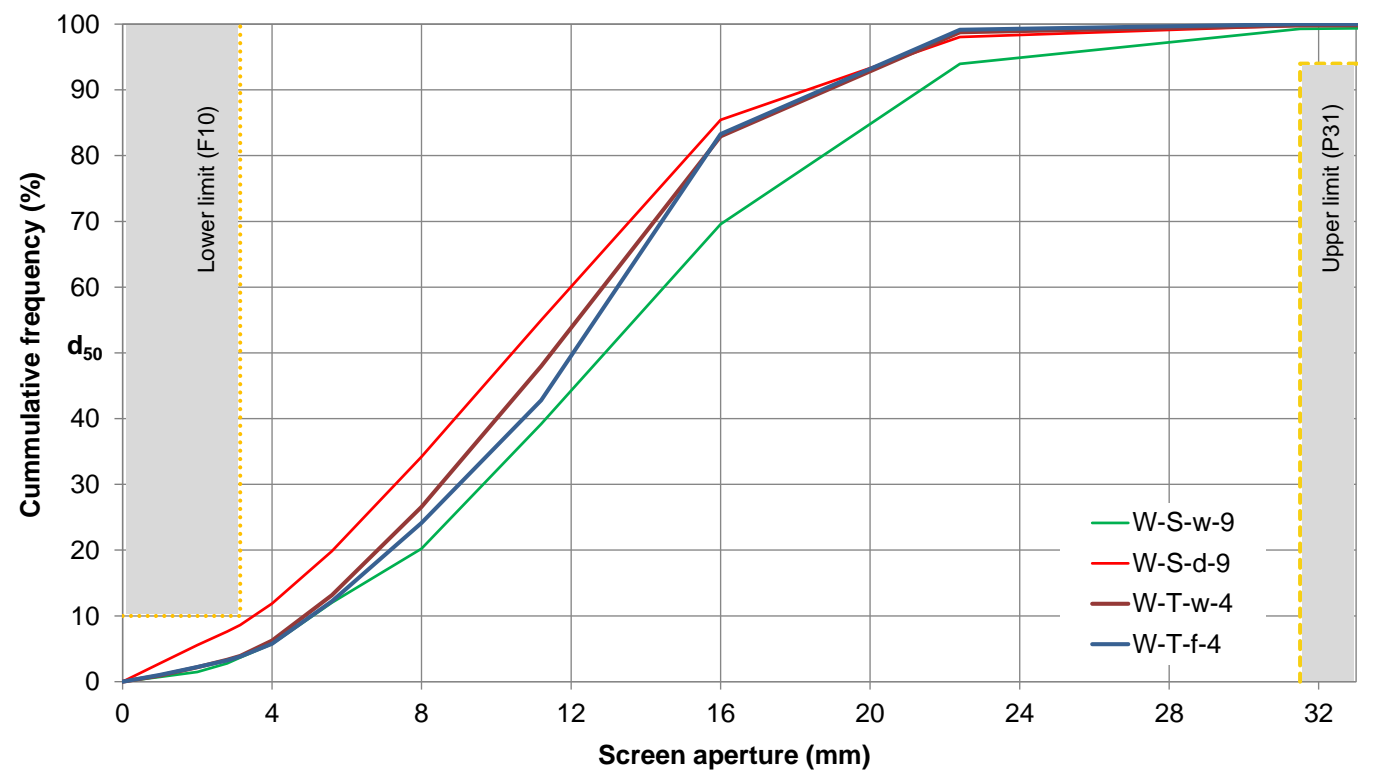

Figure 11. Particle size distribution for fine wood chips from fresh, dried and frozen willows and standard ranges according to EN ISO 17225-1; Labelling of trials: see Table 1.

Figure 11 shows the connection between drying, frost and particle size distribution for willow. While for the Salix viminalis from Germany drying led to a reduction of 19\% in the median value of the particle size after chipping, this value was increased distinctly by $10 \%$ for the Salix viminalis harvested in England (W-S-w-7 and W-S-d-7, see Table 2). It was possible to examine the influence of frost on the particle size for the variety Tordis. Here the median value for wood chips from frozen willow shoots rose by approx. 5\% (Table 2, trial W-T-W-4 and W-T-f-4). The willows of the Salix viminalis species examined form a large number of very thin shoots per stump by comparison with the Tordis variety. Therefore, bundles of nine shoots always had to be chipped to obtain a representative trial round. As can be seen from Figure 11, chipping of these shoots in dried condition lead to a distinctly higher fines fraction of $8.6 \%$.

\section{Discussion}

\subsection{Energy Demand}

The investigations conducted have shown that substantially more energy is required for chipping frozen or dried poplars and willows from short rotation coppices than for chipping fresh trees. This may have been an essential cause of the damage to the harvesting machine observed during harvesting within prolonged frost periods at temperatures well below $-5^{\circ} \mathrm{C}$. If we compare the specific energy demand required for chipping the approx. $4 \mathrm{~cm}$ thick non-frozen poplar trees $\left(4.81 \mathrm{kWh} \mathrm{t}^{-1}\right)$ with the demand required for approx. $8 \mathrm{~cm}$ thick frozen trees $\left(9.16 \mathrm{kWh} \mathrm{t}^{-1}\right)$, it is evident that here nearly twice as much comminution energy is needed-along with correspondingly higher mechanical stress upon the chipping unit of the harvesting machine. Despite being the same age, by nature the trees within a short rotation coppice plantation do not have a uniform trunk diameter. On the grounds of natural fluctuations of essential growth factors, such as for example the availability of nutrients, water and light in an SRC plantation, there is always a scatter of diameters in the tree population. Especially in edge rows and in areas adjacent to gaps among the trees, there are often considerably thicker trees [48-50]. In order to avoid damage to machinery during heavy frost periods, particular care must therefore be taken when harvesting these parts of the field. The driving speed should be reduced and with it the specific mass flow of wood to the chipping unit. One essential cause of the higher energy demand when chipping frozen trees will be the water frozen to ice inside the trees at temperatures lower than $-5^{\circ} \mathrm{C}$ [37], that now additionally has to be comminuted. At the same time 
the stems—as the particle size analysis has shown-are comminuted rather more finely. On the other hand, harvesting in frosty conditions also offers advantages, such as better trafficability of the fields. Hence, harvesting in frost can be further recommended, but outdoor temperatures lower than $-5^{\circ} \mathrm{C}$ should be avoided, and machine operators should work with special care at lower temperatures.

It was also established that chipping dried trees can be disadvantageous in energy terms as well. This was shown by the trials with the thicker stems of the poplar Max and willow (from England) varieties. Only chipping of the very thin shoots of the willow from Germany showed a reduction in the specific energy demand.

If the condition-dependent changes in the energy demand for chipping are set in relation to the energy content of the harvested material and the total energy outlay of the harvesting machines used, it becomes clear that this is, however, very slight. Taking the energy content of the poplar wood chips harvested on one hectare after four years as a basis (gross calorific value $18.5 \mathrm{MJ} \mathrm{kg}^{-1}$, yield $10 \mathrm{t}$ dry matter per year $[5,51]$ ), then the extra energy outlay is less than $0.1 \%$, even under the most unfavorable harvesting conditions. Based on the results obtained by Scholz et. al. 2011 [5] and Schweier et. al. 2016 [20] for the fuel demand of the forage harvesters frequently used for SRC harvesting (80 to $901 \mathrm{ha}^{-1}$ ), the fuel requirement of a forage harvester for harvesting would rise by up to $17 \mathrm{~L}$ per hectare-combined with a simultaneous increase in the harvesting costs. If the harvesting of frozen trees of relatively large diameter is additionally combined with higher malfunction times or damage to the machines, this can also lead to a substantial rise in the harvesting costs.

\subsection{Particle Size}

A comparison of the particle sizes obtained from chipping poplars of the same diameter makes it clear that chipping both frozen and dried stems leads to a distinct reduction of the mean wood chip size and, in connection with this, to a distinct increase in the fines fraction. Depending on the tree species, the stock and storage of the trees, this can in practice lead to a substantial reduction of the wood chip quality. Despite the quality differences determined, all the wood chips examined met the requirements of Standard EN ISO 17225-1 for the fines fraction category F10 [27]. In practice the rise in the fines fraction when chipping dried stems can at the same time be connected with an additional loss of mass in chipping. The mobile chippers used here are normally equipped with a discharge chute, via which the wood chips are blown onto a transport trailer. When producing wood chips with a high fines fraction, this leads on the one hand to high dust loads in the environment, while at the same time a larger share of the fines is lost via the airflow. These possible losses become clearest in the example of chipping the willow shoots of the Salix viminalis variety (trials W-S-w-9 and W-S-d-9). The increase in the fines fraction/the losses caused by drying amounted to 5 percentage points of the dry matter here. In this connection the dust emissions caused during chipping can also be particularly significant. Particles that have passed through the screen with an aperture width of $1 \mathrm{~mm}$ can potentially be discharged as dust during chipping [47]. As a consequence, when chipping one metric ton of dried willow shoots (Salix viminalis), up to $28 \mathrm{~kg}$ dust can be discharged. In a freshly harvested condition at most only $7 \mathrm{~kg}$ dust would result (calculated on the dry matter basis).

\section{Conclusions}

The chipping of dried or frozen poplars and willows from short rotation coppices with the usual stem diameters of more than $3 \mathrm{~cm}$ leads to a higher energy demand of $13-59 \%$ for comminution coupled with a rise in the fines fraction in the wood chips. Although harvest during frost in winter can be recommended due to improved trafficability of the fields, special care should be taken if very thick frozen trees have to be harvested with modified forage harvesters or tractor-mounted mower-chippers. Under these conditions the highest specific energy demand of all trials $\left(9.16 \mathrm{kWh} \mathrm{t}^{-1}\right.$, an increase of $41 \%$ ) has been measured-along with correspondingly higher mechanical stress for the chipping unit. However, the rise in energy demand is negligibly low by comparison with the yield of an SRC area and the energy demand for the entire process chain. 
Looking at the particle sizes produced and in particular the fines fraction, the quality of the wood chips rises when trees with larger trunk diameters are chipped. Therefore, the development of machinery for single-step harvesting of SRCs with relatively large stem diameters is recommended, but special attention needs to be paid to the increase of the mechanical stress of the chipping unit at low temperatures in winter. Furthermore, our results have shown that the fines fraction in the wood chips grows, especially when chipping thin dried stems (max. 8.9\%, willow). To what extent this affects the balance of the mass losses along the overall process chain needs to be examined in future studies. One advantage of the two-step harvesting of SRC with storage of the harvested stems can be seen in the reduced mass losses during storage and drying. To what extent this advantage is in turn relativized by process-related losses during handling of the trees during harvesting and at the storage site as well as by further losses during chipping has not so far been investigated sufficiently.

Author Contributions: Conceptualization, R.P., S.O.J. and T.H.; Methodology and experiments, R.P., S.O.J. and H.L.; Software and data validation, R.P., H.L. and T.H.; Writing-review and editing, R.P., H.L., S.O.J. and T.H. All authors have read and agreed to the published version of the manuscript.

Funding: The publication of this article was funded by the Open Access Fund of the Leibniz Association.

Acknowledgments: The authors are grateful to the Rothamsted Research, Harpenden UK (Ian Shield, Nicola Yates and Carly Whittaker) for supporting the chipping trials with willow samples. Furthermore, the authors greatly acknowledge the technical assistance of Helmuth Carl and Theodor Theodorov from ATB and the support of Benjamin Ruh from HTW Berlin during the development of the methods used for the chipping trials.

Conflicts of Interest: The authors declare no conflict of interest.

\section{References}

1. Bacenetti, J.; Pessina, D.; Fiala, M. Environmental assessment of different harvesting solutions for short rotation coppice plantations. Sci. Total Environ. 2016, 541, 210-217. [CrossRef] [PubMed]

2. Berhongaray, G.; Verlinden, M.S.; Broeckx, L.S.; Janssens, I.A.; Ceulemans, R. Soil carbon and belowground carbon balance of a short-rotation coppice: Assessments from three different approaches. GCB Bioenergy 2017, 9, 299-313. [CrossRef] [PubMed]

3. Kern, J.; Germer, S.; Ammon, C.; Balasus, A.; Bischoff, W.A.; Schwarz, A.; Forstreuter, M.; Kaupenjohann, M. Environmental effects over the first $2 \frac{1}{2}$ rotation periods of a fertilised poplar short rotation coppice. Bioenergy Res. 2017, 1-14. [CrossRef]

4. Rugani, B.; Golkowska, K.; Vázquez-Rowe, I.; Koster, D.; Benetto, E.; Verdonckt, P. Simulation of environmental impact scores within the life cycle of mixed wood chips from alternative short rotation coppice systems in Flanders (Belgium). Appl. Energy 2015, 156, 449-464. [CrossRef]

5. Scholz, V.G.; Heiermann, M.; Kern, J.; Balasus, A. Environmental impact of energy crop cultivation. $A R C H$ Agron. Soil Sci 2011, 57, 805-837. [CrossRef]

6. Whittaker, C.; Yates, N.E.; Powers, S.J.; Misselbrook, T.; Shield, I. Dry matter losses and greenhouse gas emissions from outside storage of short rotation coppice willow chip. Bioenergy Res. 2016, 9, 288-302. [CrossRef] [PubMed]

7. Scholz, V.; Boelke, B.; Burger, F.; Hofmann, M.; Hohm, C.; Lorbacher, F.R. Produktion von Pappeln und Weiden auf landwirtschaftlichen Flächen; KTBL-Kuratorium für Technik und Bauwesen in der Landwirtschaft: Darmstadt, Germany, 2008; p. 40.

8. Pecenka, R.; Lenz, H.; Idler, C. Influence of the chip format on the development of mass loss, moisture content and chemical composition of poplar chips during storage and drying in open-air piles. Biomass Bioenergy 2018, 116, 140-150. [CrossRef]

9. Kuptz, D.; Schulmeyer, F.; Hüttl, K.; Dietz, E.; Turowski, P.; Zormaier, F.; Borchert, H.; Hartmann, H. Optimale Bereitstellungsverfahren für Holzhackschnitzel; Straubing \& Freising-Weihenstephan: Straubing, Germany, 2015.

10. Kuptz, D.; Dietz, E.; Schreiber, K.; Schön, C.; Mack, R.; Wiesbeck, M.; Blum, U.; Borchert, H.; Hartmann, H. Holzhackschnitzel aus dem Kurzumtrieb - Brennstoffqualität und Verbrennungsverhalten; Straubing \& Freising-Weihenstephan: Straubing, Germany, 2018. 
11. Pari, L.; Brambilla, M.; Bisaglia, C.; Del Giudice, A.; Croce, S.; Salerno, M.; Gallucci, F. Poplar wood chip storage: Effect of particle size and breathable covering on drying dynamics and biofuel quality. Biomass Bioenergy 2015, 81, 282-287. [CrossRef]

12. Barontini, M.; Scarfone, A.; Spinelli, R.; Gallucci, F.; Santangelo, E.; Acampora, A.; Jirjis, R.; Civitarese, V.; Pari, L. Storage dynamics and fuel quality of poplar chips. Biomass Bioenergy 2014, 62, 17-25. [CrossRef]

13. Hofmann, N.; Mendel, T.; Kuptz, D.; Schulmeyer, F.; Borchert, H.; Hartmann, H. Lagerung von Holzhackschnitzeln-Trockenmasseverluste, Änderungen der Brennstoffqualität und Kosten; Straubing \& Freising-Weihenstephan: Straubing, Germany, 2017.

14. Ehlert, D.; Pecenka, R.; Wiehe, J. New principle of a mower-chipper for short rotation coppices. Landtechnik 2012, 67, 332-337. [CrossRef]

15. Faasch, R.J.; Patenaude, G. The economics of short rotation coppice in Germany. Biomass Bioenergy 2012, 45, 27-40. [CrossRef]

16. Hauk, S.; Knoke, T.; Wittkopf, S. Economic evaluation of short rotation coppice systems for energy from biomass-A review. Renew. Sustain. Energy Rev. 2014, 29, 435-448. [CrossRef]

17. Manzone, M.; Bergante, S.; Facciotto, G. Energy and economic evaluation of a poplar plantation for woodchips production in Italy. Biomass Bioenergy 2014, 60, 164-170. [CrossRef]

18. Pecenka, R.; Hoffmann, T. Harvest technology for short rotation coppices and costs of harvest, transport and storage. Agron. Res. 2015, 13, 361-371.

19. Schweier, J.; Becker, G. Economics of poplar short rotation coppice plantations on marginal land in Germany. Biomass Bioenergy 2013, 59, 494-502. [CrossRef]

20. Schweier, J. Erzeugung von Energieholz aus Kurzumtriebsplantagen auf landwirtschaftlichen Marginalstandorten in Südwestdeutschland. Ph.D.Thesis, Albert-Ludwigs-Universität Freiburg, Freiburg, Germany, February 2013.

21. Pecenka, R.; Ehlert, D.; Lenz, H. Efficient harvest lines for short rotation coppices (SRC) in agriculture and agroforestry. Agron. Res. 2014, 12, 151-160.

22. Schweier, J.; Becker, G. New Holland Forage Harvester's Productivity in Short Rotation Coppice: Evaluation of Field Studies from a German Perspective. Int. J. For. Eng. 2012, 23, 82-88. [CrossRef]

23. Vanbeveren, S.; Spinelli, R.; Eisenbies, M.; Schweier, J.; Mola-Yudego, B.; Magagnotti, N.; Acuna, M.; Dimitriou, I.; Ceulemans, R. Mechanised harvesting of short-rotation coppices. Renew. Sustain. Energy Rev. 2017, 76, 90-104. [CrossRef]

24. Eisenbies, M.H.; Volk, T.; Posselius, J.; Foster, C.; Shi, S.; Karapetyan, S. Evaluation of a Single-Pass, Cut and Chip Harvest System on Commercial-Scale, Short-Rotation Shrub Willow Biomass Crops. BioEnergy Res. 2014, 7, 1506-1518. [CrossRef]

25. Civitarese, V.; Spinelli, R.; Barontini, M.; Gallucci, F.; Santangelo, E.; Acampora, A.; Scarfone, A.; Del Giudice, A.; Pari, L. Open-Air Drying of Cut and Windrowed Short-Rotation Poplar Stems. BioEnergy Res. 2015, 8, 1614-1620. [CrossRef]

26. Schweier, J.; Becker, G. Harvesting of short rotation coppice-Harvesting trials with a cut and storage system in Germany. Silva Fenn. 2012, 46, 287-299. [CrossRef]

27. Solid Biofuels_Fuel Specifications and Classes_Part 1: General Requirements. Available online: https: //www.iso.org/standard/59456.html (accessed on 6 March 2014).

28. Solid Biofuels-Fuel Specifications and Classes-Part 4: Graded Wood Chips. Available online: https: //www.iso.org/standard/59459.html (accessed on 6 March 2014).

29. Eisenbies, M.H.; Volk, T.; Posselius, J.; Shi, S.; Patel, A. Quality and Variability of Commercial-Scale Short Rotation Willow Biomass Harvested Using a Single-Pass Cut-and-Chip Forage Harvester. BioEnergy Res. 2014, 8, 546-559. [CrossRef]

30. Lenz, H.; Pecenka, R.; Hartung, E.; Idler, C. Development and test of a simplified method to calculate dry matter loss during open-air storage of poplar wood chips by analysing ash contents. Biomass Bioenergy 2016, 94, 258-267. [CrossRef]

31. Lieskovský, M.; Jankovský, M.; Trenčiansky, M.; Merganič, J. Ash Content vs. the Economics of Using Wood Chips for Energy: Model Based on Data from Central Europe. Bioresources 2017, 12, 1579-1592. [CrossRef]

32. Liu, N.; Larsen, S.U.; Jørgensen, U.; Murach, D.; Pflugmacher, C.; Hartmann, H.; Lærke, P.E. Combustion quality of poplar and willow clones grown as SRC at four sites in Brandenburg, Germany. Biomass Bioenergy 2017, 106, 51-62. [CrossRef] 
33. Tharakan, P.; Volk, T.; Abrahamson, L.; White, E. Energy feedstock characteristics of willow and hybrid poplar clones at harvest age. Biomass Bioenergy 2003, 25, 571-580. [CrossRef]

34. Hofmann, N.; Mendel, T.; Schulmeyer, F.; Kuptz, D.; Borchert, H.; Hartmann, H. Drying effects and dry matter losses during seasonal storage of spruce wood chips under practical conditions. Biomass Bioenergy 2018, 111, 196-205. [CrossRef]

35. Pari, L.; Civitarese, V.; Del Giudice, A.; Assirelli, A.; Spinelli, R.; Santangelo, E. Influence of chipping device and storage method on the quality of SRC poplar biomass. Biomass Bioenergy 2013, 51, 169-176. [CrossRef]

36. Dimitriou, I.; Rutz, D. Sustainable short rotation coppice-A handbook. Available online: https://www. srcplus.eu/images/Handbook_SRCplus.pdf (accessed on 14 March 2019).

37. Wimmer, R. Verträgt Holz große Kälte? (Does wood tolerate strong cold?). Holzkurier 2012, 9, 24.

38. Kuptz, D.; Hartmann, H. Throughput rate and energy consumption during wood chip production in relation to raw material, chipper type and machine setting. In Proceedings of the 22nd European Biomass Conference and Exhibition, Hamburg, Germany, 23-26 June 2014.

39. Facello, A.; Cavallo, E.; Magagnotti, N.; Paletto, G.; Spinelli, R. The effect of knife wear on chip quality and processing cost of chestnut and locust fuel wood. Biomass Bioenergy 2013, 59, 468-476. [CrossRef]

40. Wegener, J.K.; Frerichs, L.; Kemper, S.; Sümening, F. Wood chipping with conical helical blades-Practical experiments concerning the impact of the infeed angle on the power requirement of a helical chipper. Biomass Bioenergy 2015, 80, 173-178. [CrossRef]

41. Krajnc, M.; Dolšak, B. The influence of drum chipper configuration on the quality of wood chips. Biomass Bioenergy 2014, 64, 133-139. [CrossRef]

42. Spinelli, R.; Cavallo, E.; Eliasson, L.; Facello, A.; Magagnotti, N. The effect of drum design on chipper performance. Renew. Energy 2015, 81, 57-61. [CrossRef]

43. Spinelli, R.; Eliasson, L.; Magagnotti, N. Increasing wood fuel processing efficiency by fine-tuning chipper settings. Fuel Process. Technol. 2016, 151, 126-130. [CrossRef]

44. Abdallah, R.; Auchet, S.; Méausoone, P.J. Experimental study about the effects of disc chipper settings on the distribution of wood chip size. Biomass Bioenergy 2011, 35, 843-852. [CrossRef]

45. Solid Biofuels—Determination of Moisture Content-Oven Dry Method-Part 2: Total Moisture-Simplified Method. Available online: https://www.iso.org/standard/71536.html (accessed on 6 May 2017).

46. Solid Biofuels_-Determination of Particle Size Distribution for Uncompressed Fuels_Part 1: Oscillating Screen Method Using Sieves with Apertures of $3.15 \mathrm{~mm}$ and above. Available online: https://www.iso.org/ standard/60685.html (accessed on 10 February 2016).

47. Schubert, H. Handbuch der mechanischen Verfahrenstechnik; Wiley-VCH Verlag GmbH \& Co.: Weinheim, Germany, 2003; p. 1273.

48. Cannell, M.G.R.; Van Noordwijk, M.; Ong, C.K. The central agroforestry hypothesis: The trees must acquire resources that the crop would not otherwise acquire. Agrofor. Syst. 1996, 34, 27-31. [CrossRef]

49. Benomar, L.; DesRochers, A.; Larocque, G.R. The effects of spacing on growth, morphology and biomass production and allocation in two hybrid poplar clones growing in the boreal region of Canada. Trees 2012, 26, 939-949. [CrossRef]

50. Gamble, J.; Johnson, G.; Sheaffer, C.C.; Current, D.A.; Wyse, N.L. Establishment and early productivity of perennial biomass alley cropping systems in Minnesota, USA. Agrofor. Syst. 2013, 88, 75-85. [CrossRef]

51. Lenz, H.; Pecenka, R.; Idler, C. In Optimum storage techniques for poplar wood from short rotation-A comparison of whole tree and fine chips storage. In Proceedings of the 23rd European Biomass Conference and Exhibition, Vienna, Austria, 1-4 June 2015.

(C) 2020 by the authors. Licensee MDPI, Basel, Switzerland. This article is an open access article distributed under the terms and conditions of the Creative Commons Attribution (CC BY) license (http://creativecommons.org/licenses/by/4.0/). 